\title{
Article
}

\section{Imagining an ideal school for wellbeing: Locating student voice}

Simmons, Catharine, Graham, Anne and Thomas, Nigel

Available at http://clok.uclan.ac.uk/11269/

Simmons, Catharine, Graham, Anne and Thomas, Nigel ORCID: 0000-00025310-9144 (2015) Imagining an ideal school for wellbeing: Locating student voice. Journal of Educational Change, 16 (2). pp. 129-144. ISSN 1389-2843

It is advisable to refer to the publisher's version if you intend to cite from the work. http://dx.doi.org/10.1007/s10833-014-9239-8

For more information about UCLan's research in this area go to

http://www.uclan.ac.uk/researchgroups/ and search for < name of research Group>.

For information about Research generally at UCLan please go to

http://www.uclan.ac.uk/research/

All outputs in CLoK are protected by Intellectual Property Rights law, including

Copyright law. Copyright, IPR and Moral Rights for the works on this site are retained by the individual authors and/or other copyright owners. Terms and conditions for use of this material are defined in the policies page.

\section{CLoK}

Central Lancashire online Knowledge www.clok.uclan.ac.uk

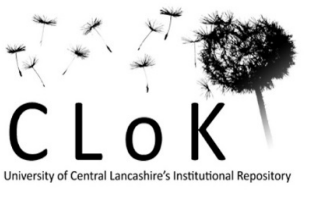




\title{
Imagining an Ideal School for Wellbeing: Locating Student Voice
}

\author{
Catharine Simmons • Anne Graham • Nigel Thomas ${ }^{1}$
}

\begin{abstract}
This article explores the significance of actively engaging with students in school about matters that concern them. The discussion draws upon data from a large-scale mixed methods study in Australia that investigated how 'wellbeing' in schools is understood and facilitated. The qualitative phase of the research included semi-structured focus group interviews with 606 students, aged between 6 and years, which incorporated an activity inviting students to imagine, draw and discuss an ideal school that promoted their wellbeing. This data reveals how capable students are of providing rich, nuanced accounts of their experience that could potentially inform school improvement. While varying somewhat across the age range involved, students identified creative ways that pedagogy, the school envi- ronment and relationships could be improved, changed or maintained to assist their wellbeing. They placed particular emphasis on the importance of opportunities to 'have a say' in relation to these matters. Such findings challenge deeply entrenched assumptions about who has the authority to speak on matters of student wellbeing, while also highlighting the potential of more democratic, participatory and inclusive approaches to change and improvement in schools.
\end{abstract}

Keywords: Relationships; Participation; Qualitative research; Student wellbeing; School improvement; Student voice.

\footnotetext{
${ }^{1}$ C. Simmons, A. Graham, Centre for Children and Young People, Southern Cross University, PO Box 157, Lismore, NSW, Australia. N. Thomas, University of Central Lancashire, Preston, UK. E-mail: catharine.simmons@scu.edu.au
} 


\section{Introduction}

Over the past 25 years much has been written internationally about effective approaches to educational change (Fullan, 2007; Hargreaves \& Shirley, 2009), including some impressive but limited attempts to position students in discussions and debates concerning school improvement and educational reform (Cook-Sather, 2006; Frost \& Holden, 2008; Kostenius, 2011; Lodge, 2005). In Australia, government and non-government education systems continue to grapple with persistent and complex issues that directly or indirectly concern students and their wellbeing. These include student retention, difficult behaviours and poor mental health, as well as the need to support students from low socio-economic status (SES) backgrounds, culturally and linguistically diverse backgrounds (CALD), and those with disabilities (Groundwater-Smith \& Kemmis, 2004; Munns, Woodward, \& Koletti, 2006). As a consequence, there has been an increased emphasis on wellbeing related research and policy in Australia (Department of Education and Communities, 2014; Noble et al., 2008), including discussion of appropriate wellbeing indicators (see ARACY, 2013). Internationally, concern about the wellbeing of children and young people is reflected in 'report cards' from organisations such as UNICEF and the Organisation for Economic Co-operation and Development (OECD), which closely monitor the performance of an increasing number of countries across a range of wellbeing indicators, including in relation to education (Organisation for Economic Co-operation and Development, 2006; UNICEF, 2013).

A number of recent reforms in Australia, including the introduction of a National Curriculum, a landmark report on school funding (Gonski et al., 2011), national professional teaching and leadership standards, and the introduction of a national disability reform agenda, have major implications for schools and school systems, including the way students, and what they 
require for success at school, are perceived (O’Meara, 2011). Additionally, funding accountability and performance requirements have also increased exponentially in recent years (Fazal \& Lingard, 2013). A dominant feature of this accountability and performance environment is the evidence schools now need to collect (including directly from children) that requires explicit, detailed information about what assists students with their learning needs, why, and how effective this is. Such developments in schools are requiring a further shift in both mindset and practice, not least of all concerning the status of students and their capacity to be more actively involved in their education.

Central to this change in mindset is the need for a more reflexive approach to the ways student 'participation' is understood in schools. For some, participation means simply attending school, while for others the focus is on participation in decision-making at school. Thus 'participation' may take place in a range of ways from turning up and attending class to involvement in formal and informal decision-making about matters relating to curriculum, culture and governance, and engagement with community (Davies, Williams, \& Yamashita, 2004; Thomas, 2007). Several helpful typologies have been developed to describe this continuum of participation (see for example, Hart, 1992; Shier, 2001) and these point to fundamental issues about power relations between adults and children, understandings of children’s agency and context relevance.

Substantial research points to the importance and benefits of children's participation in a range of contexts other than education, including in research, family law, child protection and out-of-home care (see for example, Bessell, 2011; Cashmore, 2002; Cashmore \& Parkinson, 2008; , 2010; , 2010; Thomas \& O'Kane, 2000). Much of this literature positions participation in terms of: an enlightenment rationale (children have something important to tell us that can 
lead to better outcomes for children); the promise of empowerment (a rights-based approach acknowledging children's competence/capacity); its potential for citizenship (children’s participation is about their 'place' in society, located somewhere between their current and future status as citizens) as well as its relational possibilities (participation is inherently social) (Mannion, 2007). Informing such work have been key ideas from the emerging interdisciplinary field of childhood studies (Bessell, 2009; James, Jenks, \& Prout, 1998; Thomas, 2012), alongside the United Nations Convention on the Rights of the Child (UNCRC), with children and young people now positioned as worthy of dignity, status and voice.

Despite wider developments in understanding the importance and benefits of participation, knowledge about how children and young people's participation might contribute to change and improvement in schools, remains very limited (Cook-Sather, 2006). Claims about how 'participation' is understood and facilitated in schools are largely tied to the rather ubiquitous Student Representative Councils (SRCs) and similar entities (Davies et al., 2004; Fielding, 2006). This seems paradoxical given education's role in shaping children's lives and the amount of time they spend at school. Such an approach also sits uncomfortably with Australia's obligations under the UNCRC, particularly in relation to Article 12 (United Nations Human Rights, 1989). Yet, increasing reference is now made to participation and to proxy terms such as 'student voice' in educational policy, structures and guidelines (CookSather, 2007; Mitra, 2001; Mitra \& Kirshner, 2012). While the latter infers dialogue with students about matters that affect their lives, learning and priorities at school (Lansdown, 2006), the exact nature of participation depends on who is speaking about what issues and in which context, how voice is heard and whether it is transformed into 'action' or 'agency' (2010; Holdsworth, 2000). Hence, student involvement can be tokenistic, unrepresentative in 
membership, adult-led in process and ineffective in acting upon what young people view as important (Davis \& Hill, 2006; Tisdall, 2009). This is particularly salient when it comes to matters of educational change. As Cook-Sather (2002, p.3) argues, 'there is something fundamentally amiss about building and rebuilding an entire system without consulting at any point those it is ostensibly designed to serve'.

One way of addressing such limitations is to involve students in research that is focused on educational change and reform, and on improving the experience of school. Much has now been written about the importance and legitimacy of involving children and young people in such research (Greene \& Hill, 2005; James, 2007; Tisdall, Davis, \& Gallagher, 2009). Changing conceptualisations of childhood have heightened the emphasis within research on accessing children's own understanding of their childhood experiences and taking greater account of their views (Aldgate, 2010; Christensen \& James, 2000; Pufall \& Unsworth, 2004; Tisdall \& Bell, 2006). Increasingly, children are less likely to be viewed merely as subjects or objects of inquiry, but as active participants in the research process. While students participate in a range of educational research, they tend to be positioned more as the former (objects/subjects) than the latter (active participants who shape the inquiry process).

Consistent with the notion of 'child-centred' scholarship (Kehily, 2009) and the kind of theoretical and empirical developments around childhood and participation outlined above, a major mixed-methods study has been under way in Australia that is focusing on how wellbeing is understood and facilitated in schools. The research, titled Wellbeing in Schools: What Role Does Recognition Play?, has been collecting qualitative and quantitative data from students alongside teachers and principals so as to bring their perspectives into dialogue. Underpinning the research is the assumption that educational policy and practice around 
wellbeing in schools will be significantly more responsive if it reflects the views and perspectives of students in addition to adult stakeholders.

We turn now to a brief description of the research before providing an analysis of student data in relation to one particular component of the qualitative phase, which invited students to contribute their ideas about what constitutes an 'ideal school for wellbeing'. We draw attention to the project and to these particular findings to highlight the importance of creating 'meeting places for teachers and students and for researchers and students from which to effect cultural shifts that support a repositioning of students' (Cook-Sather, 2006, p.361), particularly in terms of potential to influence positive educational change.

\section{The Wellbeing in Schools Study}

The aim of this research is to generate new knowledge about 'wellbeing' in schools that will result in improved outcomes for children and young people. Over the past two years the project has been producing systematic policy and practice-relevant evidence to advance the way children's wellbeing is understood and approached in schools. Drawing upon insights from teachers, students and existing policies, together with key ideas offered through recognition theory and Childhood Studies, the research is:

1. Developing a detailed understanding of how 'wellbeing' in schools is currently understood by students, teachers and educational policy makers;

2. Investigating the potential of recognition theory for advancing understanding and improvements in relation to student wellbeing;

3. Generating new knowledge about how educational policy, programs and practices in schools could more positively impact on student wellbeing. 
The study was conducted across Catholic School regions in three states in Australia. The views and perspectives of students and teachers, both of which are central to the research, have been sought through semi-structured interviews, focus groups and an online survey instrument. A mixed methods approach was undertaken which involved four phases, each developed with a focus on the research objectives outlined above:

Phase 1: $\quad$ Analysis of key relevant local, state and Commonwealth policy regarding wellbeing $(n=80)$

Phase 2: $\quad$ Interviews with teachers and principals ( $n=89)$; focus groups with primary and secondary students $(n=606)$

Phase 3: $\quad$ Interactive on-line survey with primary students $(n=3906)$, secondary students $(n=5,362)$ and school staff $(n=707)$ across the three school regions

Phase 4: $\quad$ Professional development for schools

Researchers have been assisted by an expert Wellbeing Advisory Group (WAG) to help guide each of the above phases. This group comprised 12 stakeholder members, including four students (two primary school, two high school), teachers, principals, school counsellors and regional office staff, as well as members of the research team.

The findings presented in this article are solely from the qualitative data gathered in Phase 2, in particular from one activity in the student focus groups that invited students to express (through drawing, writing and discussion) their views about their 'ideal school for wellbeing'. 


\section{Phase 2 student focus groups}

\section{Recruitment}

The Phase 2 focus groups were conducted with students across Years 1 and 2 (aged 6-8 years), Years 5 and 6 (aged 10-12 years), Year 8 (aged 13-14 years) and Year 11 (aged 16-17 years) in schools within the three participating regions. There were 67 focus groups from 18 schools. Focus group sizes ranged from one $(n=1)$ to $16(n=1)$, with a mode of ten $(n=28)$. In total, 606 students participated in the focus groups: Year 1-2, $n=139$; Year 5-6, $n=150$, Year $8, n=160$, Year 11, $n=157$. The focus group discussions took approximately 30 minutes for Year 1-2, and 60 minutes for Years 5-6, Year 8 and Year 11.

Primary and secondary schools were purposefully selected for Phase 2 to ensure a breadth of perspectives from the three regional school systems with a diverse range of socioeconomic, geographic and cultural characteristics. Consent was sought in accordance with the participating education systems’ requirements and university ethics protocols.

\section{Data collection}

The focus group interviews incorporated a mix of verbal, written and drawing activities that generated extensive rich data. The sessions followed a semi-structured schedule and consisted of four 'brainstorming' categories on wellbeing: students' individual definitions of wellbeing; who the students regarded as sources of support for their wellbeing; the relevance of concepts of recognition (in the sense of being 'cared for', 'respected' and 'valued') to wellbeing; and the final activity, 'imagining great schools', which is the focus of this article.

In this culminating activity, students were invited to draw or write about 'what an ideal wellbeing school might look like' while simultaneously discussing with the researcher the ideas being documented. Older students usually opted to write individually about their 
imaginary school, while the younger students (Years 1-2) preferred to draw, either as a group or individually. As such, there were three types of data collected during the focus group sessions - verbal, visual and written responses. The lists and drawings were gathered and analysed and the findings were synthesized alongside the transcriptions from the same focus group session. Prompt questions during the focus group included if schools were to take notice of what you have to say, how would they be different to now?' The primary school cohorts were asked slightly different questions, for instance the younger students were prompted with, 'what do you think is the most important thing schools can do to help students to be happy here?' and 'what would you like in school that makes you happy, safe and cared for?

This 'imaginary schools’ activity towards the end of each focus group allowed for further indepth exploration and application of what wellbeing meant to the participants and how it was facilitated in school. The drawing and writing acted as a further stimulus for student-led discussion resulting in the students having an increased personal say in the focus groups and strengthening the participatory intent of this method (Fargas-Malet, McSherry, Larkin, \& Robinson, 2010). Drawings, in particular, have been used previously in other studies to elicit children's perceptions of their environment and their lived experience (see, for example Lehman-Frisch, Authier, \& Dufaux, 2012).

\section{Analysis}

All the interview and focus group discussion data collected in Phase 2 were transcribed, coded and analysed for recurring themes to look for patterns in the data using the NVivo software program. The analysis of the data from the imaginary schools activity in the focus groups involved two stages. The first stage comprised image-only analysis. There were 
approximately 400 images gathered from the participants' drawings and/or written lists and these were collated into age cohorts and then analysed for repeated pictures and words. The second stage involved analysing the 'ideal wellbeing school' section of the related transcripts which were coded into themes alongside those generated through the 'image-only' analysis. This is in keeping with Buckingham's (2009) approach to analysing visual data, which acknowledges the inherent risk that it may not be indicative of participants' beliefs and attitudes, and hence requires researchers to engage more reflexively rather than technically. Hence, the two staged analysis process sought a more comprehensive understanding of the data gathered via different modes. For instance, rainbows were drawn regularly on the younger students' posters but not discussed during their focus groups. Alternatively, some students discussed and expanded on ideas during their conversations which were not included in their lists or images. In pursuing the kind of reflexive analysis advocated by Buckingham (2009), actively engaging the students in explicating meaning, a more accurate synthesis and representation of the three sources of data (visual, written and verbal) was intended.

\section{Findings}

The starting point for students in conceptualising an ideal school for wellbeing was understandably grounded in their current experience of school. With further prompts, an eclectic 'wellbeing school' began to emerge, some with rather utopian features. These imaginary schools had a strong grounding in communal values, such as sharing, respect, cooperation, participation and equality, as well as identifying resources to support the students' wellbeing needs. Such values were reflected within and across the four major themes that emerged in the data from both primary and secondary students, specifically concerning improvements to 1) pedagogy; 2) school environment; 3) relationships; and 4) opportunities to have a say. While these four themes were evident in the images and written 
accounts across all cohorts, the following discussion highlights some of the nuances and difference in emphasis, depending on the ages of the students.

\section{Improved pedagogy}

For students in Years 1-2 (6-8 year olds) improvements to pedagogy were mostly represented in their images as resources to support their learning. For example, they wrote and talked about: a 'tick' room (where efforts are graded), books, a library, lounge areas in the classroom as a place 'to work and read', classrooms, desks 'to work on', and 'words you can learn'. The students discussed wanting practical ways to learn, such as learning about safety through caring for dangerous animals, and learning from doing and watching. As one student stated, 'make movies at our school for watching things to help you learn'.

The students in Years 5-6 (10-12 year olds) discussed similar ideas but emphasised features such as 'outside learning', 'individual help on certain subjects', 'different ways to do a subject', 'hands-on work', 'fun learning activities', 'different activities to find out what learner you are' and 'students should write down what they want to learn about and why'. These students also put a strong emphasis on the role of their teacher in facilitating their learning. For instance, one suggestion was 'teachers that are taught from the highest universities... so they know good teaching skills and a good way to teach'. Other students mentioned how these teaching skills went hand in hand with the teachers' attitude toward the class, such as 'very open-minded teachers who don't always put grades before fun', 'honest teachers', teachers who are 'able to mingle with the students' and teachers who are not 'airyfairy'. 
As signalled earlier, the secondary school aged students in Year 8 (13-14 year olds) preferred to discuss the imaginary schools topic and then write on their posters rather than engage in drawing. The students in this age cohort also discussed the need for more skilled teachers and practical, fun lessons to enhance learning experiences. However, they were more direct and critical about issues such as the need for 'a new curriculum', 'more electives', 'learning things we actually need' and 'organised teachers'. Most of the students wanted to tailor their learning experiences through 'lifelong lessons', 'interactive lessons', 'no writing lines', 'less focus on school rules and more focus on education', 'young teachers' and 'practical lessons'. The students also wrote about learning outside and in different spaces, for instance 'once a week go outside', 'classrooms outside', and 'new environments occasionally'. Similar to the Year 5-6 students, this older age cohort often put emphasis on the teacher's responsibilities for improving these learning experiences, such as 'teachers who know their subjects'. Students in this age cohort also desired more elective choices, particularly 'more sport'.

The Year 11 students (16-17 year olds) were more orientated towards their future with a stronger emphasis on fairness and equality in pedagogical practices, such as with assessment and the way lessons are currently approached. For example, they indicated on their posters the 'need to learn in different ways to build our range of knowledge' and 'lessons for the future' and 'all exams corrected fairly and with care'. Others wrote 'more feedback on assignments', 'constructive feedback given by teachers', 'more time for homework', and students 'encouraged to put in more effort [and] not disciplined for not doing it'.

Overall, these nuanced responses across all age groups concerning pedagogy suggest that students were making a direct link between their wellbeing and the kind of teaching and learning processes they were engaged in or exposed to. Both the visual and textual data 
suggested that the students' did not perceive they had much influence over these processes even though they could articulate well the pedagogical improvements they felt needed to be made to improve wellbeing.

\section{Improved school environment - socio-emotional and physical}

Improvements to the school environment engendered feelings of happiness, fun and safety emerged across all cohorts but was especially evident in the drawings and discussions of the younger cohorts. For instance, many of the drawings from the Year 1-2 group and some of the Year 5-6 group included rainbows to symbolise happiness. Another Year 1-2 student talked about their wellbeing school as having 'love ...in the air'. Similarly, the Year 5-6 students' posters often included affective language to describe their ideal schools like 'happy', 'fun', and 'peaceful'. One student suggested that there needed to be a 'happy rule' that the principal had to enact if people were sad. Here positive feelings in school are perceived as being led by adults. The older students similarly discussed having a school that has these 'positive' attributes, as one Year 11 student stated, 'Well I think it needs to be an architecturally designed school for happiness so everything is bright... and lots of grass and stuff like that and trees to makes us feel happy'. Another wrote 'you feel good and great and happy and loving and joyful'. Such perspectives reveal the importance students place on school being a socially and emotionally supportive place through how it feels and looks.

The younger cohorts also placed a strong emphasis on the existing physical structures in the school environment as being important for their wellbeing, such as offices, classrooms, the principal's office, sick bays and churches. The Year 1-2 students' drawings also pointed to the importance of the school environment being safe. For example, some depicted being safe from fire, while others pointed to issues of security. A few students discussed having 'police' 
at their school and others stated that they wanted to have 'security guards'. These desires for safety extended to emotional as well as physical security. For instance, 'it [school] should be a place where you feel safe, a haven'; ‘the teacher makes sure you don’t get hurt...there is a gate to protect and everyone gets the same amount of respect - everyone is safe and happy'; 'there is a secret [security key] card to keep us safe from robbers'. Here, school is positioned as a sanctuary where students feel protected.

The desire for natural space was also evident across all participants, and especially for the Year 1-2 cohort, who viewed nature as integral to 'having fun' in their wellbeing school. Their drawings incorporated shady trees, sunshine, flowers, beaches and animals. The students also conveyed the desire for further facilities to be added to the natural environment, such as 'play swings', ‘a jumping castle’ and outdoor swimming pools and water slides. These were used to further convey the importance students placed on having fun and being happy at school.

Similarly, the Year 5-6 participants also highlighted their desire for more carefree leisure experiences at school as part of the physical environment, in particular sport and alternative learning spaces. In their drawings, these 'sport' spaces were often depicted as larger than learning spaces - large swimming pools, tennis courts, entertainment areas, aquatic centres, soccer/football fields. The students also drew utility rooms that would provide them with 'fun' learning experiences and, further, to relax and express themselves in school away from the classroom. For example, an 'Apple tech room', 'music vocal room', 'meditation rooms', 'boxing bag room', ‘counselling room', ‘no gravity rooms’ (to learn about space), ‘drama room', 'movie rooms' and 'art rooms'. Some students also wrote about and/or drew having bright, cheerful classrooms, such as different coloured desks and/or coloured walls. Other 
school-work resources for the environment were also discussed, mainly iPads and laptops, as well as interactive white boards. These ideas suggest that having fun alongside learning, as well as alternative spaces for leisure, are significant for the younger students' sense of wellbeing.

The Year 8 and Year 11 students also perceived the school environment to be important for their wellbeing but they tended to emphasise the physical more than the emotional environment. For instance, infrastructure featured regularly for both the Year 8 and Year 11 students: 'swimming pools', 'play equipment', 'sports ovals', 'air conditioning', 'heating' and 'clean toilets'/ 'classrooms'.

The range of ideas and concepts that emerged from the students across all cohorts highlights the importance of space and the nuanced ways they link the aesthetic and physical environment with their social and emotional needs at school.

\section{Improved relationships}

Relationships featured strongly across all cohorts. The Year 1-2 students imagined improved, caring, dispute-free relationships with teachers, the principal and friends, as well as competent teachers who could mediate conflict. In addition, there was a strong focus on the emotional support provided through relationships at school, such as feeling loved, safe, happy and cared for. For example, when asked by the interviewer why people looked so happy in their drawing, the student responded, 'because they're caring for other people' and '[caring for] the other kids in the school'. Others drew students holding hands, principals, and teachers smiling in the drawings, discussing ideas such as 'everyone is friendly', 'everyone [is] being friendly to each other', and 'a friendly school'. Another talked about the principal 
in their drawing in terms of 'he's just supervising, going around and see that the kids are safe’.

The Year 5-6 students imagined their wellbeing school as having relationships based on equality and respect - both with their friends and teachers. For instance, one student wrote 'no put downs, no excluding and no being rough'. These types of words were regularly used in their posters, with a particular emphasis on 'no bullying', and the need for inclusion. In contrast to the Year 1-2 students, these older students were better able to articulate their desire for teachers and principals who listened, were fun, showed understanding and noticed their students. For example, one student drew electronic 'tell-a-teacher' communication portals around a playground, stating that these portals were places where students could confide in a teacher if they were being bullied. This student wrote on their poster 'if you are bullied go to the 'tell-a-teacher'. Having trust in teachers was a recurring theme for the primary school cohorts, whether this pertained to issues of safety, conflict or fun. Such trust appeared to be critical for the primary school students in imagining schools as places where they felt known and cared for.

While the issue of respect was certainly implicit in the Year 1-2 and Year 5-6 drawings and narratives, the Year 8 students explicitly identified their desire for relationships with teachers and other students to be understanding and respectful. This older age cohort focused on the support schools could provide to facilitate respectful relationships and communication, evident in comments like, 'I want teachers to be more interested in us as people rather than just 'well you have to do the work'. Good relationships with peers also featured strongly, signalling a strong desire for inclusion as evidenced in 'no bullying/no peer group pressure', ‘no racism’, and, ‘no bracism’ (i.e., not being ostracised for wearing braces). 
The Year 11 participants placed even more emphasis on the importance of consultation at school and more understanding and equality in their relationships with their teachers. Issues pertaining to equality and respect were mentioned often: 'respect for students, more choice, friendship among all peers, equality, respect between teacher AND students' (student's emphasis). This cohort were more attuned to issues of power and authority and explored ways that an ideal wellbeing school might find a better balance in the power relationships between teachers and students: 'teachers take the time to ask how you are personally so you're not constantly treated as a student'; '...the rules that are made give teachers too much power [to] 'discipline' against students'. Students sought more understanding from teachers about their lives, such as increased 'check ups', and more personalised learning experiences: 'more awareness of efforts' and 'teachers more aware of [students] current issues in home life'. Overall, the Year 11 participants imagined the optimal wellbeing environment at school as one that is highly dependent on trust, warm, positive relationships, good communication and more respect and equality between teachers and students.

\section{Improved opportunities to 'have a say'}

Given this research was designed to provide students (and teachers) with the opportunity to express their views, it is not altogether unexpected to find a strong theme in the data around the importance of 'opportunities to have a say' for student wellbeing. While this theme was not as evident in data from the Year 1-2 students, the Year 5-6 students emphasised the importance of 'voice' in having a say regarding school procedures, such as 'being allowed to sit with friends', 'you're allowed to be in the same class as your friend', 'allowed to choose your teacher ', and 'students get asked on how the school should be run'. 
The Year 8 students also explicitly highlighted their desire for a school where their voice is heard, to have more of a say in decision making, and to help ensure their needs are known and supported. Some stated that they wanted opportunities for students to 'say what's on their mind' and have more 'freedom of speech', particularly in relation to matters like detentions, opportunities to 'explain yourself', canteen food and uniform choice - 'no uniform', 'lighter clothes', 'cool uniforms' and 'neat and smart uniform'.

As signalled earlier in relation to issues of power and authority in school, Year 11 students placed the notion of having a say much more centrally in their imagined wellbeing school. They asked for more voice in relation to issues such as uniform requirements, school rules (and how these rules are constructed), and more consistency with punishments. There appeared to be a stronger call for school to be a more democratic environment that prepares them for life: 'school rules that match society's rules'. The agency of the students was very evident in their desire to be able to influence change in schools.

\section{Discussion: Exploring the potential of student views in school improvement}

The 'imaginative schools' activity, conducted as part of the student focus group interviews for this research on wellbeing, provided an excellent stimulus for creative, innovative thinking about future school improvement. As evidenced in the four themes above, the students' visions of their ideal wellbeing school are heavily dependent on relationships, as reflected in approaches to pedagogy, school structures that help facilitate relationships, the importance of feeling safe and secure, the capacity to have fun, the desire for understanding, better communication, equality and respect, and more opportunities for students to be heard and involved in school life. Similar findings have been identified in other studies that have asked students to reflect on what they want improved in their schooling (see Blishen, 1969; 
Burke \& Grosvenor, 2001; Kostenius, 2011; Osler, 2010). The myriad ways in which the students, across all cohorts, implicitly and explicitly linked wellbeing with improved, caring and respectful relationships provides important direction for efforts in continual school improvement. As Eckersley (2005, p. 1) argues “...being connected and engaged...being enmeshed in a web of relationships and interests...these give meaning to our lives”. The idea of 'shared narrative' (Lodge (2005, p. 135) between students and teachers may be a challenge but has been found to be particularly useful in developing stronger, more trusting relationships and a sense of community in schools. The findings from this study underline the importance of fostering communication and respect as an integral feature of schools that promote wellbeing.

Other recent studies point to explicit benefits for policy and practice when students are actively engaged in education reform. Such benefits include a greater understanding of marginalised young people's needs and issues, a more supportive school climate, a stronger sense of belonging in school, enhanced academic and social motivation, and improved student empowerment (Earnshaw, 2014; Greig, Hobbs, \& Roffey, 2014; Mercieca \& Mercieca, 2014; Mitra, 2008; Mitra \& Serriere, 2012).

More broadly, the connection between student voice and wellbeing is now well evidenced in the literature (Aingeal de, Kelly, Molcho, Gavin, \& Saoirse Nic, 2012; Rowe, Stewart, \& Petterson, 2007) with recent policy initiatives in Australia, such as the Safe Schools Framework, advocating improved wellbeing through safety and respect (ARACY, 2013; Department of Education and Communities, 2014; Noble et al., 2008). Osler (2010), in particular, points to a lack of student voice in school as impacting on student wellbeing, stating that: 
$[\mathrm{N}]$ ot to be consulted about problems when you have insights that you believe are not shared by those making the decisions is, of course, deeply frustrating and adds to the stress of school life, impacting on relationships between students and between teachers and students. (Osler, 2010, p.74)

Nevertheless, opportunities for student voice still remain the exception rather than the norm (Kellett, 2010, p.8) with adults having the main authority to speak on matters of educational change and improvement in schools. In addition, efforts at increased student participation need to be authentic and sustainable rather than tokenistic or symbolic (see Hart, 1992; Shier, 2001), particularly given widespread concerns that students' views do not necessarily influence change or create improvements (Cairns, 2006; Kirby \& Bryson, 2002; Partridge, 2005). Such critique calls our attention to competing values and interests in regard to the 'powerful adult agendas at play' and the opportunities adults afford children and young people to 'have a say' (Clark \& Percy-Smith, 2006, p.2). Indeed, Patton et al (2000, p. 159) suggest that for participation to be fully realised and sustainable in schools there needs to be a "change in the culture of teaching toward greater collaborative relationships among teachers and students", conceding that cultural change on this level in schools is "the hardest core to crack”.

\section{Conclusion}

The findings reported in this article relate to one component of a much larger, mixed methods study on wellbeing in schools that sought the views of both students and teachers. The Phase 2 student focus groups incorporated an activity that invited primary and secondary school cohorts to imagine their ideal school for wellbeing and to represent this using drawings and text. These creative artefacts, along with the transcribed discussion that took place in relation 
to them, provided rich insights into how schools might look and feel in the future (see also Blishen 1969, 2001).

While the accounts from students in this research lend strong support to Soutter's (2011) view that students "have been an untapped resource in contemporary wellbeing research", an obvious limitation is that one-off data collection may not provide sufficient time for students to critically reflect on their views of wellbeing over time, in different settings, including individual as well as collective contexts. Hence, the identified "conundrum associated with communicating the individual and collective voices of children in research” (Gillett-Swan, 2014, p. 67) might be lessened with more prolonged engagement in the field. Nevertheless, the depth of dialogue and richness of the views conveyed through the imaginary schools focus group activity, across three school regions, highlighted the value students placed on being consulted and having a say in relation to their wellbeing.

The students' emphasis on the significance of pedagogy, environment, relationships and student voice for improving wellbeing is not ostensibly in conflict with the aspirations of much current educational policy (Authors et al., in progress). While the qualitative findings presented here have now been confirmed by extensive quantitative data collected in Phase 3 of the study and reported elsewhere, (Authors et al., in progress), it is important to ensure the nuances identified in the drawings, text and discussion in Phase 2 are also given close consideration. Doing so may help to ensure that policy, programs and practice in relation to student wellbeing in schools remains responsive to the views, needs and concerns of the children and young people whose lives they intend to improve. 


\section{Acknowledgements}

The authors would like to acknowledge the funders of this research: the Australian Research Council (ARC); the Catholic Schools Office, Lismore; Interrelate; and Good Grief Ltd. Particular thanks to other members of the project team and to the many schools involved in this research - the principals and teachers who so generously gave their time and expertise and especially the students whose views, perspectives and imaginations were integral to the project and to this particular paper. Thanks also to Emeritus Professor Bettina Cass for her helpful comments on early drafts of this article.

\section{References}

Aingeal de, R., Kelly, C., Molcho, M., Gavin, A., \& Saoirse Nic, G. (2012). Is school participation good for children? Associations with health and wellbeing. Health Education, 112(2), 88-104. doi: http://dx.doi.org/10.1108/09654281211203394

Aldgate, J. (2010). Child well-being, child development and family life. In C. McAuley \& W. Rose (Eds.), Child Well-being: Understanding Children's Lives. London: Jessica Kingsley Publishers.

ARACY. (2013). Report card: The wellbeing of young Australians. ACT: Australian Research Alliance for Children and Youth (ARACY).

Bessell, S. (2009). Children's participation in decision-making in the Philippines: Understanding the attitudes of policy-makers and service providers. Childhood: A Global Journal of Child Research, 16(3), 299-316.

Bessell, S. (2011). Promoting children's protection and participation (Vol. 6). Lismore: Southern Cross University, Lismore, Centre for Children and Young People.

Buckingham, D. (2009). 'Creative' visual methods in media research: Possibilities, problems and proposals. Media, Culture \& Society, 31(4), 633-652. doi: 10.1177/0163443709335280 
Cairns, L. (2006). Participation with purpose. In E. K. M. Tisdall, J. M. Davis, A. Prout \& M. Hill (Eds.), Children, young people and social inclusion : Participation for what? (pp. 216-235). Bristol: Policy Press.

Cashmore, J. (2002). Promoting the participation of children and young people in care. Child Abuse \& Neglect, 26, 837-847.

Cashmore, J., \& Parkinson, P. (2008). Children's and parents' perceptions of children's participation in decision-making after parental separation and divorce. Legal Studies Research Paper, 08/48, $1-27$.

Christensen, P., \& James, A. (Eds.). (2000). Research with Children: Perspectives and Practices. London: RoutledgeFalmer Press.

Clark, A., \& Percy-Smith, B. (2006). Beyond consultation: participatory practices in everyday spaces. Children, Youth and Environments, 16(2), 1-9.

Cook-Sather, A. (2002). Authorizing students' perspectives:Towards trust, dialogue, and change in education. Educational Researcher, 31(4), 3-14.

Cook-Sather, A. (2006). Sound, presence, and power: "Student Voice" in educational research and reform. Curriculum Inquiry, 36(4), 359-390.

Cook-Sather, A. (2007). Resisting the impositional potential of student voice work: Lessons for liberatory educational research from poststructuralist feminist critiques of critical pedagogy. Discourse: Studies in the Cultural Politics of Education, 28(3), 389-403.

Davies, L., Williams, C., \& Yamashita, H. (2004). Inspiring schools: A literature review: Taking up the challenge of pupil participation. London: Carnegie Young People Initiative.

Davis, J. M., \& Hill, M. (2006). Introduction. In E. K. M. Tisdall, J. M. Davis, M. Hill \& A. Prout (Eds.), Children, Young People and Social Inclusion: Participation for what? (pp. pp. 1-22). Bristol: The Policy Press.

Department of Education and Communities. (2014). The National Safe Schools Framework. Retrieved from https://www.education.gov.au/national-safe-schools-framework-0. 
Earnshaw, O. (2014). Learning to be a child: A conceptual analysis of youth empowerment. Educational \& Child Psychology, 31(1), 13-21.

Eckersley, R. (2005). What is Wellbeing, and What Promotes It? Background to a Manifesto for Wellbeing. In T. A. Institute (Ed.), The Wellbeing Manifesto. Canberra: The Australia Institute.

Fargas-Malet, M., McSherry, D., Larkin, E., \& Robinson, C. (2010). Research with children: methodological issues and innovative techniques. Journal of Early Childhood Research, 8(2), 175-192.

Fazal, R., \& Lingard, B. (2013). Globalizing education policy. Online: Taylor and Francis.

Fielding, M. (2006). Leadership, radical student engagement and the necessity of person-centred education. Leadership in Education, 9(4), 299-313.

Frost, R., \& Holden, G. (2008). Student voice and future schools: building partnerships for student participation. Improving Schools, 11, 83-95.

Fullan, M. (2007). The new meaning of educational change (Fourth ed.). New York, USA: Teacher's College Press.

Gillett-Swan, J. K. (2014). Investigating twen children's capacity to conceptualise the complex issue of wellbeing. Global Studies of Childhood, 4(2), 64-76.

Gonski, D., Boston, K., Greiner, K., Lawrence, C., Scales, B., \& Tannock, P. (2011). Review of Funding for Schooling: Final Report: Australian Government.

Greene, S., \& Hill, M. (2005). Researching children's experience: methods and methodological issues. In D. Hogan \& S. Greene (Eds.), Researching children's experience: Methods and approaches (pp. 1-21). London: Sage.

Greig, A., Hobbs, C., \& Roffey, S. (2014). Guest Editorial: Empowering Young People. Educational \& Child Psychology, 31(1), 6-12.

Groundwater-Smith, S., \& Kemmis, S. (2004). Knowing makes the difference: Learnings from the NSW Priority Action Schools Program Findings of the independent meta-evaluation study NSW Department of Education and Training. 
Hargreaves, A. P., \& Shirley, D. L. (2009). The fourth way: The inspiring future for educational change. USA: Corwin Press.

Hart, R. (1992). Children's participation: From tokenism to citizenship. Florence: UNICEF.

Holdsworth, R. (2000). Schools that create real roles of value for young people. Prospects, 30(3), 349-362. doi: 10.1007/bf02754058

James, A. (2007). Giving voice to children's voices: Practices and problems, pitfalls and potentials. American Anthropologist, 109(2), 261-272.

James, A., Jenks, C., \& Prout, A. (1998). Theorizing Childhood. Cambridge: Polity.

Kehily, M. (2009). An Introduction to Childhood Studies (2nd ed.). London: Open University Press.

Kellett, M. (2010). Small shoes big steps! Empowering children as active researchers. American Journal of Community Scholarship, 46, 8.

Kirby, P., \& Bryson, S. (2002). Measuring the magic? Evaluating and researching young people's participation in public decision making. London: Carnegie Young People Initiative.

Kostenius, C. (2011). Picture this - our dream school! Swedish schoolchildren sharing their visions of school. Childhood, 18(4), 509-525.

Lansdown, G. (2006). International developments in children's participation. In K. Tisdall, J. Davis, M. Hill \& A. Prout (Eds.), Children, young people and social inclusion: Participation for what? (pp. 139-178). Bristol: Policy Press.

Lehman-Frisch, S., Authier, J.-Y., \& Dufaux, F. (2012). 'Draw me your neighbourhood': a gentrified Paris neighbourhood through its children's eyes. Children's Geographies, 10(1), 17-34. doi: $10.1080 / 14733285.2011 .638175$

Lodge, C. (2005). From hearing voices to engaging in dialogue: Problematising student participation in school improvement. Journal of Educational Change, 6(2), 125-146. doi: 10.1007/s10833005-1299-3

Mannion, G. (2007). Going spatial, going relational: Why 'listening to children' and children's participation needs reframing. Discourse: Studies in the Cultural Politics of Education, 28(3), 405-420. 
Mercieca, D., \& Mercieca, D. P. (2014). EPs becoming ignorant : Questioning the assumption of listening and empowerment in young children. Educational \& Child Psychology, 31(1), 2231.

Mitra, D. (2001). Opening the floodgates: Giving students a voice in school reform. Forum, 43(2), 9194.

Mitra, D., \& Kirshner, B. (2012). Insiders versus outsiders: Examining variability in student voice initiatives and their consequences for school change. In B. McMahon \& J. Portelli (Eds.), Student engagement in urban schools: Beyond neoliberal discourses. Charlotte, NC: Information Age Publishing.

Mitra, D. L. (2008). Amplifying Student Voice. Educational Leadership, 66(3), 20-25.

Mitra, D. L., \& Serriere, S. C. (2012). Student voice in elementary school reform: Examining youth development in fith graders. American Educational Research Journal, 49(4), 743-774.

Munns, G., Woodward, H., \& Koletti, J. (2006). Engagement and student self-assessment. In G. Munns, J. Lawson, M. O'Brien \& K. Johnson (Eds.), School is for me: pathways to student engagement. Sydney: Fair Go Project, NSW Department of Education and Training, University of Western Sydney.

Noble, T., McGrath, H., Roffey, S., Rowling, L., Carbines, R., \& Robb, L. (2008). Scoping study into approaches to student wellbeing: Final Report. DEEWR, ACT: Department of Education, Employment and Workplace Relations (DEEWR), ACU National, Erebus International.

O’Meara, J. (2011). Australian teacher education reforms: Reinforcing the problem or providing a solution? Journal of Education for Teaching: International Research and Pedagogy, 37(4), 423-431.

Organisation for Economic Co-operation and Development. (2006). Starting Strong II: Early Childhood Education and Care: Organisation for Economic Co-operation and Development (OECD).

Osler, A. (2010). Students' Perspectives on Schooling. New York, USA: Open University Press.

Partridge, A. (2005). Children and young people's inclusion in public decision-making. Support for Learning, 20(4), 181-189. 
Patton, G., Glover, S., Bond, L., Butler, H., Godfrey, C., Pietro, G., \& Bowes, G. (2000). The Gatehouse Project: A systematic approach to mental health promotion in secondary schools. Australian and New Zealand Journal of Psychiatry, 34(4), 586.

Pufall, P., \& Unsworth, R. (Eds.). (2004). Rethinking Childhood. London: Rutgers Press.

Rowe, F., Stewart, D., \& Petterson, C. (2007). Promoting school connectedness through whole school approaches. Health Education, 107(6), 524-542.

Shier, H. (2001). Pathways to participation: Openings, opportunities and obligation. Children \& Society: The International Journal of Childhood and Children's Services, 15, 107-117.

Soutter, A. (2011). What can we learn about wellbeing in school? . Journal of Student Wellbeing, $5(1), 1-21$.

Thomas, N. (2007). Towards a theory of children's participation. International Journal of Children's Rights, 15(2), 199-218.

Thomas, N. (2012). Love, rights and solidarity: Studying children's participation using Honneth's theory of recognition. Childhood, 19(4), 453-466.

Thomas, N., \& O'Kane, C. (2000). Discovering what children think: Connections between research and practice. British Journal of Social Work, 30(6), 819-835.

Tisdall, E. (2009). Theorising children's participation: Learning across countries and across disciplines. Paper presented at the Seminar funded by the Leverhulme Trust, 6-8 April, Cape Town, South Africa.

Tisdall, E., \& Bell, R. (2006). Included in governance? Children's participation in 'public' decision making. In K. Tisdall, J. Davis, A. Prout \& M. Hill (Eds.), Children, Young People and Social Inclusion: Participation for What? (pp. 103-119). Bristol: Policy Press.

Tisdall, E., Davis, J. M., \& Gallagher, M. (2009). Researching with Children and Young People: Research Design, Methods, and Analysis. London: Sage.

UNICEF. (2013). Child well-being in rich countries: A comparitive review. In P. Adamson (Ed.), Report Card 11. Florence: Innocenti.

United Nations Human Rights. (1989). Article 12: Convention on the Rights of the Child. New York: United Nations. 
